\title{
An assessment of tropical cyclones rainfall erosivity for Taiwan
}

\author{
Jayalakshmi Janapati ${ }^{1,7}$, Balaji Kumar Seela $\mathbb{C}^{1,2,7}$, Pay-Liam Lin ${ }^{1,3^{*}}$, Pao K. Wang $\mathbb{(}^{4,5}$ \& \\ Utpal Kumar 6
}

Rainfall erosivity (or water erosion) has severe implications on agriculture, water, and land use management. Though, there were Rainfall erosivity studies on regional and global scale, tropical cyclones' Rainfall erosivity is poorly assessed and have not been documented for one of the most cyclones affecting regions of the world like Taiwan. Here, using 15 -years of raindrop size distributions (RSD) and 60-years of hourly rain gauges data, we estimated cyclones (also called typhoons) rainfall erosivity over Taiwan, and establish that typhoons' mean rainfall erosivity is higher than the global mean rainfall erosivity. Moreover, regional variability of typhoons rainfall erosivity showed an increasing pattern from north to south (Taipei to Pingtung), with relatively higher values over eastern and southern parts of Taiwan. The annual mean erosivity of typhoons rainfall showed raising trends over eastern and southern Taiwan during 1958-2017. Our results provide an insight in assessing the land use and agricultural management for Taiwan.

Tropical cyclones cause devastating loss of life and property globally ${ }^{1,2}$. Taiwan is one of the most intense tropical cyclones (typhoons) prone areas in the world ${ }^{3}$ with an average number of 3-4 typhoons striking the island every year ${ }^{4}$. Typhoons' rainfall extremes over Taiwan are accountable for more sediment discharge $e^{5,6}$, natural hazards like floods, debris flow, and landslides ${ }^{7-10}$. Typhoons-induced rainfall kinetic energy (KE) is the driving force for surface runoff and landslide, and can be used as a proxy to determine the landslides triggering ${ }^{11}$. The rainfall KE is the key parameter in the estimation of rainfall erosivity factor (or R-factor), a substantial factor for soil erosion risk assessment in Universal Soil Loss Equation (USLE), Revised Universal Soil Loss Equation (RUSLE), and RUSLE2 $2^{12-15}$. The ability of rainfall to cause soil erosion can be described in terms of R-factor, and its variability immensely influences the agriculture, water, and land use management. The R-factor of a given location is defined as the annual accumulation of $\mathrm{EI}_{30}$ index (in $\mathrm{M} \mathrm{J} \mathrm{mm} \mathrm{ha}^{-1} \mathrm{~h}^{-1}$ ): the product of kinetic energy of each event $(\mathrm{E})$ and its maximum 30-min rainfall intensity $\left(\mathrm{I}_{30}\right)^{12,14}$. An apprehending of $\mathrm{R}$-factor can prominently improves an accurate assessment of soil erosion.

Since the direct measurement of rainfall KE requires a precise and expensive experimental setup ${ }^{16,17}$, alternative approaches have been developed to compute the rainfall KE from rainfall intensity (I $)^{18,19}$, which require empirical relations between KE and I. As the KE of raindrop is proportional to the third power of diameter and square of fall velocity, the combined information of raindrop size and fall velocity of rain allows us to derive KE-I relations ${ }^{18-21}$. The KE-I relations have been developed in the form of linear ${ }^{22}$, exponential ${ }^{18,23}$, power ${ }^{24}$, and logarithmic ${ }^{25}$, which are effective for the observational site or to the regions with similar geographical and meteorological characteristics ${ }^{21,23-25}$, and vary with geographical location, local climate and precipitation microphysics ${ }^{18,20,23}$.

Although, most of the previous studies on R-factor were devoted to seasonal or annual basis at regional, national, continental and global level ${ }^{26-31}$, limited studies were reported on the basis of storm types ${ }^{32}$, even such study has the limitation due to the adaptation of elsewhere KE-I relations in evaluating the R-factor. Here 'elsewhere' refers to the other country's KE-I relations. Due to the paucity of local KE-I relations, vast majority of

\footnotetext{
${ }^{1}$ Institute of Atmospheric Physics, Department of Atmospheric Sciences, National Central University, Jhong-Li Region, Tao-Yuan City, Taiwan. ${ }^{2}$ Taiwan International Graduate Program (TIGP), Earth System Science Program, Research Center for Environmental Changes, Academia Sinica, Taipei, Taiwan. ${ }^{3}$ Earthquake-Disaster \& Risk Evaluation and Management Center, National Central University, Jhong-Li Region, Tao-yuan City, Taiwan. ${ }^{4}$ Department of Atmospheric and Oceanic Sciences, University of Wisconsin-Madison, Madison, Wisconsin, USA. ${ }^{5}$ Research Center for Environmental Changes, Academia Sinica, Taipei, Taiwan. ${ }^{6}$ Taiwan International Graduate Program (TIGP), Earth System Science Program, Institute of Earth Sciences, Academia Sinica, Taipei, and National Central University, Jhong-Li Region, Tao-Yuan City, Taiwan. ${ }^{7}$ These authors contributed equally: Jayalakshmi Janapati and Balaji Kumar Seela. *email: tliam@pblap.atm.ncu.edu.tw
} 
rainfall erosivity studies have adopted elsewhere KE-I relations $s^{15,31,32}$ and only limited researchers used their local KE-I relations ${ }^{33}$. Similar scenario can be seen even for Taiwan in estimating the typhoons rainfall KE/erosivity ${ }^{11}$, which may lead to overestimation or underestimation of typhoons rainfall erosivity for this island ${ }^{19,33-35}$. Though, there were reports on local KE-I relations for Taiwan, they are limited to the seasonal rainfall or combination of monsoon and typhoon rainfall ${ }^{36,37}$. Moreover, the raindrop size distribution (RSD) characteristics of tropical cyclones and their KE-I relations were found to be different from that of the non-tropical cyclones precipitation $^{19,38-40}$. Henceforth, it is crucial to explore Taiwan typhoons R-factor by adopting indigenous KE-I relations.

Here, we use the long-term RSD of 65 typhoons (2002-2017) and dense network of hourly rain gauges data (1958-2017). We investigate and evaluate the KE-I relations for typhoon rainfall, and demonstrate that the power form of KE-I relation is appropriate. Furthermore, the rainfall erosivity (R-factor) and erosivity density (R-factor density) are assessed for 393 typhoon rainfall events (occurred during 1958-2017) by adopting the estimated power form of KE-I relation to all rain gauge stations distributed over Taiwan. Also, trends in typhoons' rainfall erosivity across the Island are discussed.

\section{Results}

The rainfall statistics of 75 typhoon rainfall erosive events computed from RSD measurements of disdrometer during 2002-2017 are summarized in Table 1. The rainfall depth, number of particles, duration of the event, maximum and mean rainfall intensity of these 75 typhoon events varies from $10.43-355.75 \mathrm{~mm}, 31175-1615753$, 159-6900 $\mathrm{min}, 9.97-143.17 \mathrm{~mm} \mathrm{~h}^{-1}$ and $0.24-14.22 \mathrm{~mm} \mathrm{~h}^{-1}$, respectively. The number of particles range, 31175 to 1615753 , represents the number of raindrops recorded by the JWD for 75 typhoon rainfall events. Out of 75 typhoon rainfall events, we used 72 events (70600 data points) to establish the empirical relations between kinetic energy (Kinetic energy expenditure - $\mathrm{KE}_{\text {time, }}$ and kinetic energy content $-\mathrm{KE}_{\mathrm{mm}}$ ) and rainfall intensity (I) by using nonlinear least square regression analysis. The rest three events (Fungwong, Lupit, and Namtheun: designated with * symbol, in bold and italic font in Table 1$)$ are used to validate the derived KE-I ( $\left.\mathrm{KE}_{\text {time }}-\mathrm{I}_{\text {and }} \mathrm{KE}_{\mathrm{mm}}-\mathrm{I}\right)$ relations.

Establishment of kinetic energy-rainfall intensity (KE-I) relations. Figure 1a depicts the scatter plot for kinetic energy expenditure $\left(\mathrm{KE}_{\text {time }}\right)$ and intensity (I) data points (70600) for 72 typhoon rainfall events. The $\mathrm{KE}_{\text {time }}$ ranges from $0.1-3517.9 \mathrm{~J} \mathrm{~m}^{-2} \mathrm{~h}^{-1}$, corresponding to rainfall intensities of $0.1-123.4 \mathrm{~mm} \mathrm{~h}^{-1}$. The mean value of $\mathrm{KE}_{\text {time }}$ is $72.65 \mathrm{~J} \mathrm{~m}^{-2} \mathrm{~h}^{-1}$ with standard deviation of $194.75 \mathrm{~J} \mathrm{~m}^{-2} \mathrm{~h}^{-1}$. The best estimates for power 24,41 and linear ${ }^{22}$ forms of $\mathrm{KE}_{\text {time }}$-I relations from the regression analysis are given Fig. 1a. The regression line derived for the data points showed relatively higher coefficient of determination for both power and linear equations. Even so, for rainfall intensity $>50 \mathrm{~mm} \mathrm{~h}^{-1}$, the $\mathrm{KE}_{\text {time }}$ is underestimated by the linear equation and the power equation created good estimates with its regression line approximately passing through middle of data points, and the data points are relatively least scattered with uniform distribution over power regression line.

A total number of 70600 one-min data points of kinetic energy content $\left(\mathrm{KE}_{\mathrm{mm}}\right)$ and intensity (I) are shown in Fig. 1b. The $\mathrm{KE}_{\mathrm{mm}}$ varies from $1.05-39.11 \mathrm{~J} \mathrm{~m}^{-2} \mathrm{~mm}^{-1}$ for the rainfall intensity values of $0.1-123.4 \mathrm{~mm} \mathrm{~h}^{-1}$ with mean and standard deviation of $11.14 \mathrm{~J} \mathrm{~m}^{-2} \mathrm{~mm}^{-1}$ and $5.79 \mathrm{~J} \mathrm{~m}^{-2} \mathrm{~mm}^{-1}$, respectively. The maximum $\mathrm{KE}_{\mathrm{mm}}$ of current typhoons is higher than the global average maximum $\mathrm{KE}_{\mathrm{mm}}\left(28.3 \pm 2.9 \mathrm{~J} \mathrm{~m}^{-2} \mathrm{~mm}^{-1}\right)^{20}$. The $\mathrm{KE}_{\mathrm{mm}}$ data points are more scattered at lower rainfall intensities $\left(<15 \mathrm{~mm} \mathrm{~h}^{-1}\right)$ and are getting narrowed with the increase of rainfall intensity. By excluding the higher $\mathrm{KE}_{\mathrm{mm}}$ values at lower rainfall intensities $\left(<15 \mathrm{~mm} \mathrm{~h}^{-1}\right)$, a maximum $\mathrm{KE}_{\mathrm{mm}}$ of $35.71 \mathrm{~J} \mathrm{~m}^{-2} \mathrm{~mm}^{-1}$ is noticed. For rainfall intensity greater than $75 \mathrm{~mm} \mathrm{~h}^{-1}$, the $\mathrm{KE}_{\mathrm{mm}}$ ranges from $23.61-$ $34.11 \mathrm{~J} \mathrm{~m}^{-2} \mathrm{~mm}^{-1}$ with mean and standard deviation of $26.4 \mathrm{~J} \mathrm{~m}^{-2} \mathrm{~mm}^{-1}, 1.61 \mathrm{~J} \mathrm{~m}^{-2} \mathrm{~mm}^{-1}$, respectively. The established power, linear, logarithmic ${ }^{25}$, and exponential ${ }^{18,23}$ fitting curves for $\mathrm{KE}_{\mathrm{mm}}$ and I are depicted in Fig. $1 \mathrm{~b}$.

Among four models (Fig. 1b), power model showed relatively higher performance, and other two models (exponential and logarithmic) are significantly underestimated the $\mathrm{KE}_{\mathrm{mm}}$ for rainfall intensities $>30 \mathrm{~mm} \mathrm{~h}^{-1}$. The exponential form of $\mathrm{KE}_{\mathrm{mm}}$-I relation in the present study is different from that of the Chang et al. ${ }^{37}\left(\mathrm{KE}_{\mathrm{mm}}=32.19\right.$ $\left.\left[1-0.725 \mathrm{e}^{-0.0291}\right]\right)$, which is due to their collective consideration of both seasonal and typhoon rainfall RSD in deriving $\mathrm{KE}_{\mathrm{mm}}$-I relations. Present exponential form of $\mathrm{KE}_{\mathrm{mm}}$-I relation is also found to be different from that of the Van Dijk et al. ${ }^{20}$ generalized equation $\left(\mathrm{KE}_{\mathrm{mm}}=28.3[1-0.52 \exp (-0.042 \mathrm{I})]\right)$ and evidently shows that the KE-I relations of typhoon rainfall are different from that of the non-typhoon rainfall, and confirms that, there is need to adopt local tropical cyclones KE-I relations in computing the rainfall KE/erosivity of tropical cyclones of a given region.

The goodness-of-fit statistics in terms of coefficient of determination $\left(\mathrm{R}^{2}\right)$, root mean square error (RMSE), and normalized RMSE (NRMSE) for power, linear, logarithmic and exponential equations of KE-I relations for 72 events are provided in Table 2. From the Table 2, amid four regression models (power, linear, logarithmic and exponential), statistically the power law showed higher predictive capability for the two erosivity indices $\left(\mathrm{KE}_{\text {time }}\right.$ and $\mathrm{KE}_{\mathrm{mm}}$, Fig. 1). Similar characteristics were reported by the previous researchers elsewhere ${ }^{40}$.

Validation of kinetic energy-rainfall intensity (KE-I) relations. It is important to endorse the estimated KE-I relations before using them in rainfall erosivity assessment, and so, we validated the derived empirical (KE-I) relations with three typhoon events (Event no. 35, 39, and 40 in Table 1). Among these three events, two events have higher rainfall intensities with long (Event no. 35. Fungwong) and short (Event no. 40. Namtheun) duration, and the third one (Event no. 39. Lupit) has long duration and relatively low rainfall intensities, but this is quite erosive if the whole event is considered. Figure $2 \mathrm{a}-\mathrm{c}$ represents $\mathrm{KE}_{\text {time }}$ versus I for three events with linear and power relations. For Fungwong and Namtheun events (Fig. 2a,c), estimation of $\mathrm{KE}_{\text {time }}$ by power law showed a good performance and underestimated by linear law at higher rainfall intensity $\left(>35 \mathrm{~mm} \mathrm{~h}^{-1}\right)$. In the case of the Lupit event (Fig. 2b), even if both power and linear laws overestimated, the power law shows more predictive capability than liner law. The goodness-of-fit statistics ( $\mathrm{R}^{2}$, RMSE, and NRMSE) for power and liner forms of 


\begin{tabular}{|c|c|c|c|c|c|c|c|c|}
\hline \multirow[b]{2}{*}{ S. No. } & \multirow[b]{2}{*}{ Typhoon name } & \multirow[b]{2}{*}{ Date and start time } & \multirow[b]{2}{*}{$\begin{array}{l}\text { Duration } \\
\text { (minutes) }\end{array}$} & \multirow[b]{2}{*}{$\begin{array}{l}\text { No. of } \\
\text { particles }\end{array}$} & \multirow[b]{2}{*}{$\begin{array}{l}\text { Rainfall } \\
\text { depth }(\mathbf{m m})\end{array}$} & \multicolumn{3}{|c|}{ Rainfall intensity $\left(\mathrm{mm} \mathrm{h}^{-1}\right)$} \\
\hline & & & & & & Maximum & Mean & \begin{tabular}{|l|} 
Standard \\
deviation
\end{tabular} \\
\hline 1 & Sinlaku & 5/9/2002 15:06 & 1907 & 285175 & 32.28 & 38.35 & 1.02 & 2.51 \\
\hline 2 & Mindule & 2/7/2004 1:00 & 1649 & 586270 & 90.71 & 56.47 & 3.3 & 6.23 \\
\hline 3 & Rananim & 10/8/2004 19:15 & 1614 & 323349 & 77.17 & 86.8 & 2.87 & 10.12 \\
\hline 4 & Aere & $23 / 08 / 04$ 09:35 & 2631 & 656241 & 228.97 & 76.36 & 5.22 & 8.12 \\
\hline 5 & Songda & 5/9/2004 6:10 & 230 & 52118 & 10.43 & 46.03 & 2.72 & 6.13 \\
\hline 6 & Songda & 6/9/2004 0:09 & 159 & 54525 & 18.89 & 57.36 & 7.13 & 11.94 \\
\hline 7 & Haima & 8/9/2004 1:10 & 661 & 153702 & 12.16 & 34.72 & 1.1 & 3.04 \\
\hline 8 & Haima & 9/9/2004 14:10 & 487 & 98361 & 37.68 & 70.06 & 4.64 & 10.28 \\
\hline 9 & Haima & 10/9/2004 12:10 & 3205 & 1564637 & 277.54 & 98.06 & 5.2 & 10.87 \\
\hline 10 & Meari & 25/09/04 05:40 & 1542 & 183809 & 13.86 & 26.54 & 0.54 & 1.98 \\
\hline 11 & Tokge & 18/10/04 10:12 & 1702 & 835644 & 21.47 & 9.97 & 0.76 & 1.13 \\
\hline 12 & Nock-ten & $24 / 10 / 0401: 21$ & 3611 & 927626 & 84.8 & 96.23 & 1.41 & 5.07 \\
\hline 13 & Nanmdol & 3/12/2004 1:53 & 2257 & 543890 & 67.57 & 33.83 & 1.8 & 2.7 \\
\hline 14 & Haitang & 17/07/05 06:59 & 3687 & 925339 & 222.61 & 88.86 & 3.62 & 8.25 \\
\hline 15 & Matsa & 4/8/2005 3:51 & 2437 & 750259 & 217.67 & 101.06 & 5.36 & 9.75 \\
\hline 16 & Talim & $31 / 08 / 05$ 01:40 & 1804 & 280064 & 84.87 & 67.72 & 2.82 & 6.84 \\
\hline 17 & Khanun & 10/9/2005 11:10 & 854 & 213791 & 12.89 & 30.06 & 0.91 & 2.54 \\
\hline 18 & Darmey & 22/09/05 01:04 & 1502 & 221685 & 45.98 & 55.97 & 1.84 & 4.61 \\
\hline 19 & Longwong & 1/10/2005 8:52 & 1477 & 261609 & 60.66 & 101.94 & 2.46 & 8.17 \\
\hline 20 & Chanchu & $16 / 05 / 0602: 27$ & 2570 & 236904 & 32.29 & 12.31 & 0.75 & 1.88 \\
\hline 21 & Chanchu & 19/05/06 00:38 & 482 & 59018 & 11.94 & 35.87 & 1.49 & 4.09 \\
\hline 22 & Ewiniar & $8 / 7 / 200620: 06$ & 759 & 175041 & 65.09 & 118.67 & 5.15 & 14.64 \\
\hline 23 & Bilis & 12/7/2006 9:15 & 5053 & 732898 & 70.73 & 54.55 & 0.84 & 2.71 \\
\hline 24 & Kaemi & \begin{tabular}{|l|}
$25 / 07 / 06 ~ 14: 24$ \\
\end{tabular} & 1660 & 77646 & 18.02 & 52.37 & 0.65 & 3.42 \\
\hline 25 & Saoma & $8 / 8 / 200612: 34$ & 1115 & 93451 & 15.34 & 49.68 & 0.83 & 3.83 \\
\hline 26 & Bopha & 9/8/2006 23:57 & 726 & 132751 & 24.11 & 61.19 & 1.99 & 6.55 \\
\hline 27 & Shanshan & 12/9/2006 01:16 & 1364 & 191698 & 54.3 & 92.04 & 2.39 & 7.01 \\
\hline 28 & Shanshan & 13/09/06 06:37 & 500 & 131165 & 32.39 & 68.11 & 3.89 & 9 \\
\hline 29 & Shanshan & $15 / 09 / 06 \quad 07: 17$ & 3644 & 435828 & 39.95 & 65.78 & 0.66 & 2.73 \\
\hline 30 & Pubak & 7/8/2007 09:00 & 2220 & 77064 & 10.83 & 11.59 & 0.29 & 0.82 \\
\hline 31 & Wutip & $14 / 08 / 07$ 08:30 & 382 & 81251 & 43.29 & 63.56 & 6.8 & 16.37 \\
\hline 32 & Sepat & 17/08/07 13:07 & 3209 & 129099 & 19.04 & 24.65 & 0.36 & 1.23 \\
\hline 33 & Wipha & 17/09/07 06:01 & 3733 & 968851 & 96.16 & 49.19 & 1.55 & 3.3 \\
\hline 34 & Mitag & 26/11/07 03:40 & 2660 & 574797 & 74.29 & 22.47 & 1.68 & 2.41 \\
\hline 35 & *Fungwong & 26/07/08 22:26 & 4015 & 335743 & 124.67 & 143.17 & 1.86 & 10.14 \\
\hline 36 & Sinlaku & 11/9/2008 06:02 & 6676 & 1615753 & 355.75 & 83.96 & 3.2 & 7.55 \\
\hline 37 & Jangmi & 27/09/08 02:10 & 4552 & 586699 & 140.82 & 86.5 & 1.86 & 4.61 \\
\hline 38 & Parma & $4 / 10 / 2009$ 10:30 & 3690 & 495127 & 65.35 & 16.89 & 1.06 & 1.83 \\
\hline 39 & *Lupit & 22/10/09 10:29 & 4361 & 678629 & 27.7 & 12.95 & 0.38 & 0.99 \\
\hline 40 & *Namtheun & $30 / 08 / 1002: 28$ & 247 & 52710 & 26.59 & 122.77 & 6.46 & 21.26 \\
\hline 41 & Namtheun & $30 / 08 / 10$ 13:30 & 315 & 215043 & 74.65 & 92.85 & 14.22 & 18.51 \\
\hline 42 & Meranti & 10/9/2010 16:13 & 359 & 57103 & 26.14 & 70.17 & 4.37 & 11.77 \\
\hline 43 & Megi & $18 / 10 / 1002: 40$ & 6900 & 973252 & 102.58 & 37.1 & 0.89 & 2.12 \\
\hline 44 & Songda & $27 / 05 / 1109: 38$ & 1914 & 604537 & 19.04 & 21.5 & 0.6 & 1.33 \\
\hline 45 & Sarika & 10/6/2011 16:32 & 304 & 31175 & 15.03 & 75.47 & 2.97 & 10.04 \\
\hline 46 & Meari & $24 / 06 / 11$ 17:37 & 1784 & 205498 & 26.36 & 14.65 & 0.89 & 2.02 \\
\hline 47 & Muifa & 6/8/2011 17:39 & 639 & 68809 & 22.09 & 54.83 & 2.07 & 7.52 \\
\hline 48 & Talim & $18 / 06 / 1213: 21$ & 4711 & 789295 & 85.89 & 65.97 & 1.09 & 3.4 \\
\hline 49 & Saola & $30 / 07 / 1200: 25$ & 5500 & 1199496 & 296.2 & 81.02 & 3.23 & 7.33 \\
\hline 50 & Haikui & 6/8/2012 7:03 & 458 & 62019 & 11.55 & 45.55 & 1.51 & 4.61 \\
\hline 51 & Tembin & 22/08/12 08:45 & 2181 & 304661 & 105.94 & 97.66 & 2.91 & 11.06 \\
\hline 52 & Bolavin & $26 / 08 / 1200: 50$ & 1390 & 93594 & 22.39 & 62.61 & 0.97 & 4.68 \\
\hline 53 & Sanba & $14 / 09 / 1200: 25$ & 2855 & 315352 & 130.45 & 93.31 & 2.74 & 9.22 \\
\hline 54 & Bopha & $8 / 12 / 20120: 00$ & 1960 & 622973 & 40.19 & 13.04 & 1.23 & 1.52 \\
\hline 55 & Soulik & $12 / 7 / 20130: 48$ & 2037 & 326205 & 85.41 & 42.12 & 2.52 & 4.87 \\
\hline
\end{tabular}




\begin{tabular}{|c|c|c|c|c|c|c|c|c|}
\hline \multirow[b]{2}{*}{ S. No. } & \multirow[b]{2}{*}{ Typhoon name } & \multirow[b]{2}{*}{ Date and start time } & \multirow[b]{2}{*}{$\begin{array}{l}\text { Duration } \\
\text { (minutes) }\end{array}$} & \multirow[b]{2}{*}{$\begin{array}{l}\text { No. of } \\
\text { particles }\end{array}$} & \multirow[b]{2}{*}{$\begin{array}{l}\text { Rainfall } \\
\text { depth }(\mathbf{m m})\end{array}$} & \multicolumn{3}{|c|}{ Rainfall intensity $\left(\mathrm{mm} \mathrm{h}^{-1}\right)$} \\
\hline & & & & & & Maximum & Mean & \begin{tabular}{|l|} 
Standard \\
deviation
\end{tabular} \\
\hline 56 & Soulik & $14 / 07 / 1307: 25$ & 1821 & 79771 & 12.82 & 22.26 & 0.42 & 1.6 \\
\hline 57 & Kongrey & $28 / 08 / 1300: 24$ & 2856 & 545091 & 111.84 & 104.98 & 2.35 & 8.02 \\
\hline 58 & Toraji & 30/08/13 00:00 & 3469 & 719941 & 46.65 & 54.87 & 0.81 & 2.47 \\
\hline 59 & Usagi & 19/09/13 19:16 & 4002 & 270513 & 44.07 & 58.44 & 0.66 & 3.69 \\
\hline 60 & Fitow & 4/10/2013 0:29 & 3691 & 300156 & 31.2 & 68.99 & 0.51 & 2.93 \\
\hline 61 & Matmo & 22/07/14 08:00 & 2400 & 244233 & 55.24 & 48.12 & 1.38 & 3.03 \\
\hline 62 & Fungwang & 21/09/14 08:00 & 1080 & 194242 & 89.98 & 123.4 & 5 & 13.79 \\
\hline 63 & Vongfong & $8 / 10 / 201417: 39$ & 4660 & 422190 & 39.18 & 54.11 & 0.5 & 2.48 \\
\hline 64 & Noul & $11 / 5 / 20150: 18$ & 1422 & 85864 & 16.45 & 56.4 & 0.69 & 4.24 \\
\hline 65 & Chanchom & 9/7/2015 2:05 & 2225 & 337854 & 42.67 & 63.18 & 1.15 & 4.41 \\
\hline 66 & Soudelor & 6/8/2015 11:29 & 322 & 37851 & 19.87 & 91.08 & 3.7 & 13.05 \\
\hline 67 & Soudelor & 7/8/2015 0:00 & 1301 & 213187 & 73.9 & 69.41 & 3.41 & 7.02 \\
\hline 68 & Goni & 22/08/15 13:12 & 2088 & 104937 & 17.69 & 86.26 & 0.51 & 4.14 \\
\hline 69 & Goni & 24/08/15 20:58 & 344 & 165002 & 22.11 & 47.36 & 3.86 & 6.14 \\
\hline 70 & Dujuan & 26/09/15 03:52 & 4088 & 976602 & 91.77 & 52.2 & 1.35 & 3.6 \\
\hline 71 & Meranti & 12/9/2016 1:52 & 3263 & 326550 & 13.32 & 35.43 & 0.24 & 1.17 \\
\hline 72 & Malakas & 16/09/16 07:18 & 2442 & 592981 & 45.43 & 52.86 & 1.12 & 3.54 \\
\hline 73 & Megi & 26/09/16 02:46 & 2595 & 589245 & 136.59 & 66.95 & 3.16 & 6.62 \\
\hline 74 & Nesat/Haitang & 29/07/17 01:47 & 1333 & 113150 & 13.59 & 22.35 & 0.61 & 1.44 \\
\hline 75 & Talim & $12 / 09 / 1716: 47$ & 2113 & 196436 & 21.93 & 69.06 & 0.62 & 3.59 \\
\hline
\end{tabular}

Table 1. Rainfall statistics (Date, duration, no. of particles, rainfall depth, and intensity) of 75 typhoon rainfall erosive events observed by disdrometer. The "No. of particles" column represents the number of raindrops measured by the disdrometer for each typhoon event.
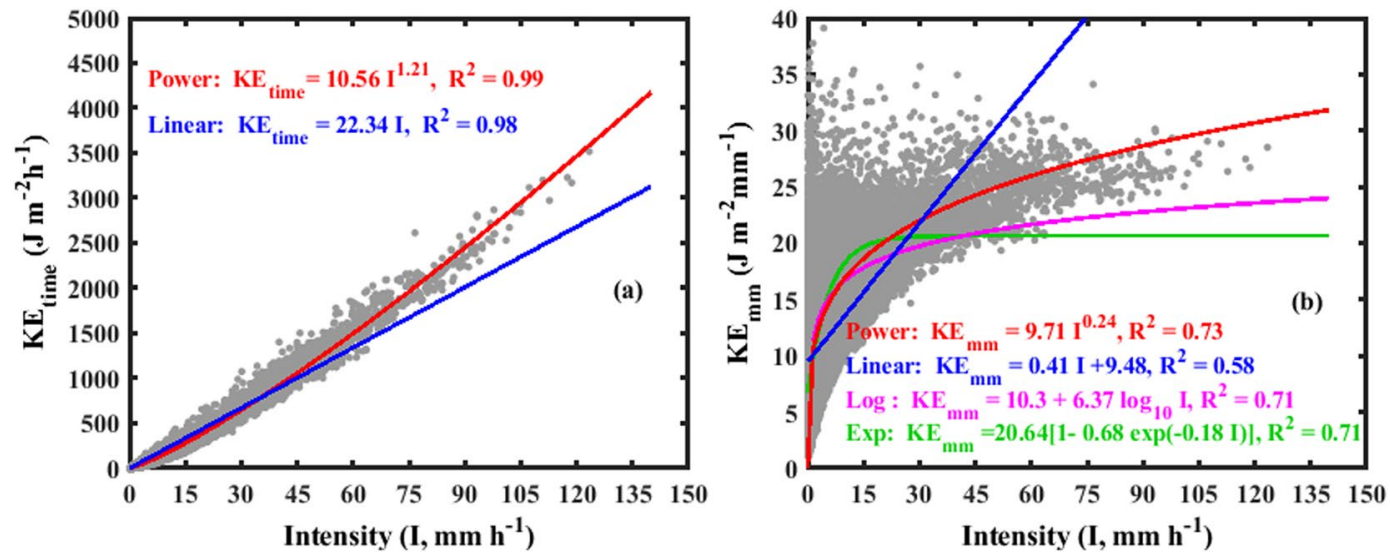

Figure 1. Scatter plot of typhoon rainfall (a) kinetic energy expenditure $\left(\mathrm{KE}_{\text {time }}\right)$ and Intensity (I) fitted with linear and power laws $(\mathbf{b})$ kinetic energy content $\left(\mathrm{KE}_{\mathrm{mm}}\right)$ and Intensity (I) fitted with linear, power, logarithmic and exponential equations for 73 typhoon rainfall events (70600 1-min data points).

$\mathrm{KE}_{\text {time }}-\mathrm{I}$ relations are quantified in Table 2. Even though two equations showed relatively higher coefficient of determination $\left(\mathrm{R}^{2}\right)$, the power law showed lower RMSE and NRMSE, indicating that the power law has better performance than linear in estimating the $\mathrm{KE}_{\text {time }}$ from rainfall intensity.

Validation of power, linear, logarithmic, and exponential forms of $\mathrm{KE}_{\mathrm{mm}}$-I relations with three events (Event no. 35, 39, and 40) are shown in Fig. 2d-f. In all the three events (Fig. 2d-f), power, logarithmic and exponential relations showed similar prediction capability for lower rainfall intensities $\left(<5 \mathrm{~mm} \mathrm{~h}^{-1}\right)$. Exponential and logarithmic fits severely underestimated the $\mathrm{KE}_{\mathrm{mm}}$ for event no. 35 (for I $>30 \mathrm{~mm} \mathrm{~h}^{-1}$ ) and event no. 40 (for I $>40 \mathrm{~mm} \mathrm{~h}^{-1}$ ). The $\mathrm{KE}_{\mathrm{mm}}$ is well predicted by the power equation for long duration- high intensity rainfall event (Event no. 35. Fungwong, Fig. 2d), nonetheless, $\mathrm{KE}_{\mathrm{mm}}$ is overestimated for remaining two events (Event no. 39 and 40 ). The goodness-of-fit statistics ( $\mathrm{R}^{2}, \mathrm{RMSE}$, and NRMSE) for power, linear, logarithmic and exponential equations of $\mathrm{KE}_{\mathrm{mm}}$-I relations are provided in Table 2 for the three typhoon events. Further, estimated KE-I models ( $\mathrm{KE}_{\text {time }}-\mathrm{I}$ : linear, power, $\mathrm{KE}_{\mathrm{mm}}$-I: linear, power, logarithmic, and exponential) are cross-validated by using leave $p$ out cross validation method (where $p=3$ events), and the iterations were performed for 1000 times. We found that the power model is more reliable than the other models for both $\mathrm{KE}_{\mathrm{time}}-\mathrm{I}$ and $\mathrm{KE}_{\mathrm{mm}}-\mathrm{I}$ relations. 


\begin{tabular}{|c|c|c|c|c|c|c|c|}
\hline \multirow[b]{2}{*}{ Typhoon } & \multirow{2}{*}{$\begin{array}{l}\text { Statistical } \\
\text { parameters }\end{array}$} & \multicolumn{2}{|c|}{$\mathrm{KE}_{\text {time }}-\mathrm{I}$} & \multicolumn{4}{|l|}{$\mathrm{KE}_{\mathrm{mm}}-\mathrm{I}$} \\
\hline & & Power & Linear & logarithmic & Exponential & Power & Linear \\
\hline \multirow{3}{*}{$\begin{array}{l}72 \text { rainfall } \\
\text { events }\end{array}$} & $\mathrm{R}^{2}$ & 0.99 & 0.98 & 0.71 & 0.72 & 0.72 & 0.58 \\
\hline & Rmse & 23.10 & 40.28 & 4.07 & 4.05 & 3.99 & 4.72 \\
\hline & Nrmse & 0.19 & 0.33 & 4.07 & 4.05 & 0.03 & 4.72 \\
\hline \multirow{3}{*}{ Fungwong } & $\mathrm{R}^{2}$ & 0.99 & 0.99 & 0.72 & 0.71 & 0.76 & 0.65 \\
\hline & RMSE & 65.15 & 135.87 & 4.68 & 4.72 & 4.36 & 5.74 \\
\hline & NRMSE & 0.45 & 0.95 & 0.03 & 0.03 & 0.03 & 0.04 \\
\hline \multirow{3}{*}{ Lupit } & $\mathrm{R}^{2}$ & 0.97 & 0.95 & 0.47 & 0.47 & 0.48 & 0.45 \\
\hline & RMSE & 9.66 & 24.89 & 4.80 & 4.49 & 4.60 & 5.23 \\
\hline & NRMSE & 0.75 & 1.94 & 0.37 & 0.35 & 0.36 & 0.41 \\
\hline \multirow{3}{*}{ Namtheun } & $\mathrm{R}^{2}$ & 0.99 & 0.99 & 0.96 & 0.95 & 0.97 & \begin{tabular}{|l|}
0.89 \\
\end{tabular} \\
\hline & RMSE & 81.05 & 153.95 & 2.93 & 3.59 & 2.99 & 9.73 \\
\hline & NRMSE & 0.66 & 1.25 & 0.02 & 0.03 & 0.02 & 0.08 \\
\hline
\end{tabular}

Table 2. Statistical parameters [correlation coefficient: $\mathrm{R}^{2}$, Root mean square error (RMSE), normalized RMSE] of 72 events and the three events selected for validation.

Because of spurious self-correlations between $\mathrm{KE}_{\mathrm{mm}}$ and $\mathrm{I}$, and relatively higher $\mathrm{KE}_{\mathrm{mm}}$ values at lower rainfall intensities, the $\mathrm{KE}_{\mathrm{mm}}-\mathrm{I}$ relations lead to uncertainty in predicting the rainfall $\mathrm{KE}^{21}$ for larger I values. This characteristics is clearly persistent even for present typhoon rainfall events (Fig. 1b). Hence, we prefer to adopt $\mathrm{KE}_{\text {time }}-\mathrm{I}$ relation rather than $\mathrm{KE}_{\mathrm{mm}}$-I relation in computing the rainfall erosivity and was strongly suggested ${ }^{21}$.

Spatial variation of typhoon rainfall, rainfall erosivity and erosivity density. During 1958-2017, with Central Weather Bureau (CWB) typhoon warning periods, a total number of 423 typhoons were recorded by dense network of 711 rain gauge stations over Taiwan, and among 423 typhoons 393 were qualified for the erosive event criteria. Nevertheless, in the current study, in order to estimate the representative typhoons rainfall erosivity, rain gauge stations (288) with minimum record period of 20 years ${ }^{14}$, whose elevation ranges from $2-3844.8 \mathrm{~km}$ asl are adopted. These 288 rain gauge stations have typhoon events for a total number of 7227 years with a mean value of 25 years per station, with number of events ranging from 58 to 368 . The erosivity factor $\left(\mathrm{EI}_{30}\right)$ of 393 typhoons over 288 rain gauge stations are computed by applying the estimated KE-I relation.

The annual mean precipitation, rainfall erosivity, and erosivity density of 393 typhoons over Taiwan are depicted in Fig. 3. The estimated stations' annual mean precipitation ranges from 196.76 to $1427.3 \mathrm{~mm} \mathrm{yr}^{-1}$, with mean and standard deviation of $578.97 \mathrm{~mm} \mathrm{yr}^{-1}$ and $231.04 \mathrm{~mm} \mathrm{yr}^{-1}$, respectively. The Island-wide gridded annual mean precipitation values are derived by applying kriging interpolation to stations' annual mean precipitation. The gridded annual mean typhoons-induced rainfall varies from $288.57-877.79 \mathrm{~mm} \mathrm{yr}^{-1}$, with mean and standard deviation value of $586.90 \mathrm{~mm} \mathrm{yr}^{-1}$ and $155.44 \mathrm{~mm} \mathrm{yr}^{-1}$, respectively (Fig. 3a). The spatial distribution of typhoons precipitation depicts relatively higher values over eastern and south eastern part of Taiwan. Different (north, east, central, and south) regions of Taiwan are depicted with different color in Supplementary Fig. 1b. The typhoons-induced event rainfall amounts contributed to a percentage of $14.3 \%, 25.7 \%, 29.1 \%$, and $30.9 \%$, respectively, for north, central, east, and south regions of Taiwan. The deep central mountain ranges (CMR) of Taiwan helps in enhancing the convective activity of typhoons while they cross it, resulting in relatively higher precipitation over eastern and south eastern part of Taiwan than other areas ${ }^{42}$. The strong easterly winds of typhoons are blocked by the CMR leading to less precipitation across west coast of Taiwan ${ }^{43}$. Annual mean precipitations of Taiwan Counties are detailed in Table 3.

The R-factor values of 288 rain gauges with record period of 20-60 years varied from 886.75-22653.03 MJ mm $\mathrm{ha}^{-1} \mathrm{~h}^{-1} \mathrm{yr}^{-1}$, with mean and standard deviation value of, respectively, $4880.74 \mathrm{MJ} \mathrm{mm} \mathrm{ha} \mathrm{m} \mathrm{h}^{-1} \mathrm{yr}^{-1}$ and 3261.97 MJ mm ha ${ }^{-1} \mathrm{~h}^{-1} \mathrm{yr}^{-1}$. The Island-wide gridded annual mean R-factor values are derived by applying kriging interpolation to stations' annual mean R-factors. The gridded R-factor values differs from 1005.73-9787.41 MJ $\mathrm{mm} \mathrm{ha} \mathrm{C}^{-1} \mathrm{~h}^{-1} \mathrm{yr}^{-1}$, with mean and standard deviation value of $4905.83 \mathrm{MJ} \mathrm{mm} \mathrm{ha}{ }^{-1} \mathrm{~h}^{-1} \mathrm{yr}^{-1}$ and $1882.69 \mathrm{MJ} \mathrm{mm}$ $\mathrm{ha}^{-1} \mathrm{~h}^{-1} \mathrm{yr}^{-1}$, respectively (Fig. 3b). Regional variability of typhoons R-factor showed an increasing pattern from north to south, with relatively higher values over eastern and southern part of Taiwan (Fig. 3b). As mentioned in the above paragraph, typhoons-induced event rainfall amounts contribute to a percentage of $14.3 \%, 25.7 \%$, $29.1 \%$, and $30.9 \%$, respectively, for north, central, east, and south regions of Taiwan. Similarly, typhoon-induced rainfall erosivity contributed to a percentage of $9.3 \%, 25 \%, 28.1 \%$ and $37.2 \%$, respectively, for north, central, east, and south regions of Taiwan. Typhoons invading region of Taiwan is surrounded by two major typhoon paths over the northwest Pacific region. One path moves south of Taiwan in westward to the south China sea, and the other turns in the north direction toward either Japan or Korea, which pass through the east side of Taiwan ${ }^{44}$. Because of steeper height of the central mountain range (CMR) of Taiwan, which is extended from north to south of the Taiwan Island, majority of the typhoons are blocked by these CMR, resulting in higher rainfall amounts over eastern and southern part of Taiwan (Fig. 3a), subsequently, relatively higher erosivity values over eastern and southern part of Taiwan. The regions with higher R-factor over Taiwan are in order with the higher precipitations areas (Fig. 3a). In addition to that, a good correlation is observed between precipitation (P) and $\mathrm{EI}_{30}$ values at event as well as annual wise (Supplementary Fig. 4), and the $\mathrm{EI}_{30}-\mathrm{P}$ relations at event and annual level are estimated as, respectively, $\mathrm{EI}_{30}=0.68 \mathrm{P}^{1.44}\left(\mathrm{R}^{2}=0.80\right)$ and $\mathrm{EI}_{30}=1.69 \mathrm{P}^{1.23}\left(\mathrm{R}^{2}=0.86\right)$. For the mostly 



Figure 2. Validation of estimated $\mathrm{KE}_{\text {time }}-\mathrm{I}$ relations $(\mathbf{a}-\mathbf{c}), \mathrm{KE}_{\mathrm{mm}}-\mathrm{I}(\mathbf{d}-\mathbf{f})$ in the form of linear (blue color), power (red color), exponential (green color), and logarithmic (pink color) laws with Fungwong (Event no. 35), Lupit (Event no. 39), and Namtheun (Event no. 40) typhoon events, respectively.

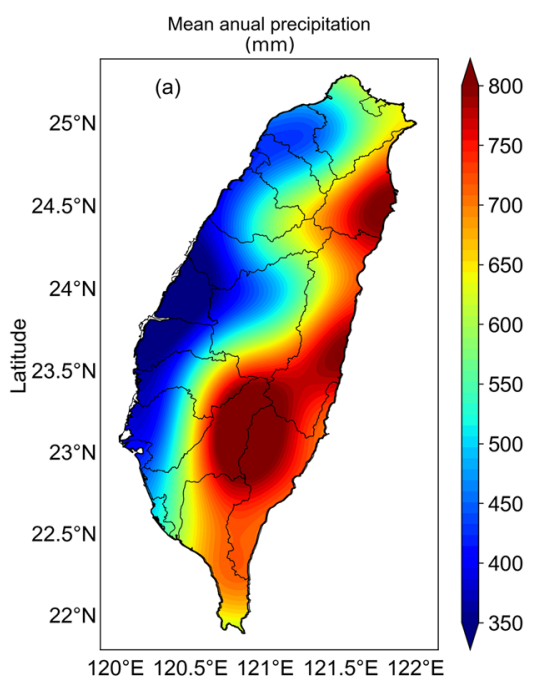

Longitude

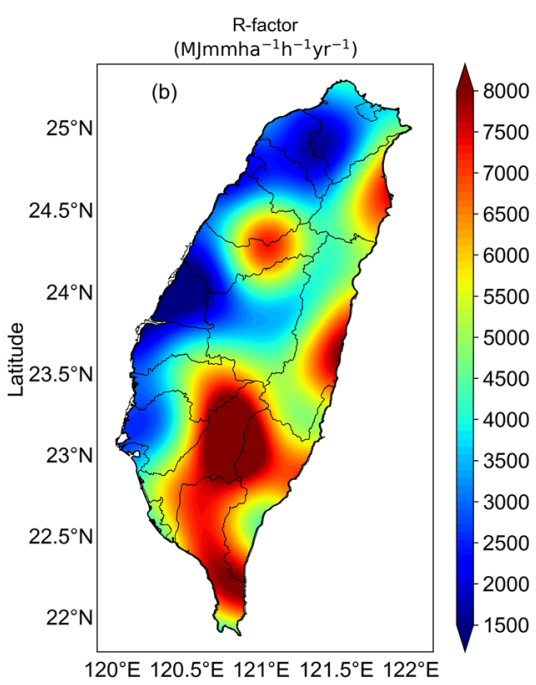

Longitude

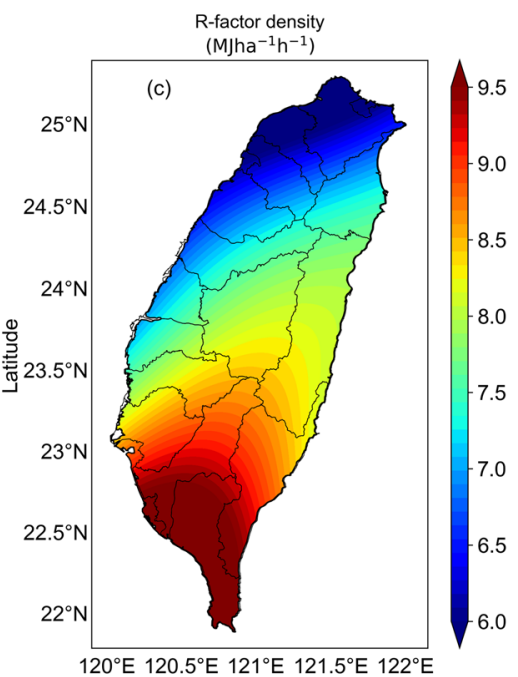

Longitude

Figure 3. Spatial distribution of typhoons-induced (a) mean annual precipitation (b) R-factor, and (c) R-factor density map plotted with kriging over Taiwan during 1958-2017.

associated tropical cyclones rainfall over Pacific coast of Mexico, García-Oliva et al. ${ }^{45}$ perceived mean annual erosivity of $6525.2 \mathrm{MJ} \mathrm{mm} \mathrm{ha}{ }^{-1} \mathrm{~h}^{-1}$. Recently, Laceby et al. ${ }^{32}$ demonstrated that tropical cyclones contributed $22 \%$ of precipitation and $40 \%$ of rainfall erosivity over Fukushima region of Japan, and they illustrated that the annual mean precipitation and R-factor ranged from, respectively, 68 to $639 \mathrm{~mm} \mathrm{yr}^{-1}$ (mean: $422 \mathrm{~mm} \mathrm{yr}^{-1}$ ) and 142 to $4547 \mathrm{MJ} \mathrm{mm} \mathrm{ha} \mathrm{h}^{-1} \mathrm{~h}^{-1} \mathrm{yr}^{-1}$ (mean: $1462 \mathrm{MJ} \mathrm{mm} \mathrm{ha}^{-1} \mathrm{~h}^{-1} \mathrm{yr}^{-1}$ ). Storm wise variation of mean precipitation and $\mathrm{EI}_{30}$ ranged from $41-240 \mathrm{~mm}$ and $118-1695 \mathrm{MJ} \mathrm{mm} \mathrm{ha}^{-1} \mathrm{~h}^{-1}$, respectively, (Table S1. of Laceby et al. ${ }^{32}$ ). However, for Taiwan region, event mean precipitation and $\mathrm{EI}_{30}$ of typhoons varied, respectively, from $12.5-3059.5 \mathrm{~mm}$ and 0.47-92144.9 MJ mm ha ${ }^{-1} \mathrm{~h}^{-1}$, which are greater than the values over Japan. This demonstrates that the typhoons rainfall over Taiwan has much influence with intense rainfall and higher $\mathrm{EI}_{30} / \mathrm{R}$ factor values. Further, annual 


\begin{tabular}{|c|c|c|c|c|c|c|c|c|c|c|c|c|c|}
\hline \multirow[b]{2}{*}{ County } & \multirow{2}{*}{$\begin{array}{l}\text { No. of } \\
\text { rain } \\
\text { gauges }\end{array}$} & \multicolumn{2}{|c|}{$\begin{array}{l}\begin{array}{l}\text { Number of } \\
\text { years }\end{array} \\
\end{array}$} & \multicolumn{2}{|c|}{$\begin{array}{l}\text { Accumulated } \\
\text { precipitation }(\mathrm{mm})\end{array}$} & \multicolumn{2}{|c|}{$\begin{array}{l}\text { Annual mean } \\
\text { precipitation } \\
\left(\mathrm{mm} \mathrm{yr}^{-1}\right)\end{array}$} & \multicolumn{2}{|c|}{$\begin{array}{l}\mathrm{EI}_{30} \\
\left(\mathrm{MJ} \mathrm{ha}^{-1} \mathrm{~mm} \mathrm{~h}^{-1}\right)\end{array}$} & \multicolumn{2}{|c|}{\begin{tabular}{|l} 
R-factor \\
$\left(\mathrm{MJ} \mathbf{h a}^{-1} \mathrm{~mm}\right.$ \\
$\left.\mathrm{h}^{-1} \mathrm{yr}^{-1}\right)$ \\
\end{tabular}} & \multicolumn{2}{|c|}{$\begin{array}{l}\text { R-factor } \\
\text { density } \\
\left(\mathrm{MJ} \mathbf{h a}^{-1} \mathbf{h}^{-1}\right)\end{array}$} \\
\hline & & Min. & Max & Mean & SD & Mean & SD & Mean & SD & Mean & SD & Mean & SD \\
\hline Taipei & 28 & 20 & 60 & 17269.3 & 15165.9 & 553.2 & 223.0 & 99874.0 & 108511.8 & 3095.5 & 1725.2 & 5.3 & 1.01 \\
\hline Tauyoun & 8 & 20 & 26 & 10317.7 & 5363.0 & 453.5 & 248.9 & 56569.6 & 56277.3 & 2539.3 & 2752.2 & 4.7 & 1.95 \\
\hline Hsinchu & 11 & 21 & 26 & 11432.2 & 5382.3 & 456.7 & 196.1 & 68901.7 & 62573.2 & 2720.5 & 2366.3 & 5.2 & 1.83 \\
\hline Yilan & 23 & 20 & 59 & 18828.8 & 6299.0 & 781.8 & 228.9 & \begin{tabular}{|l|}
147759.0 \\
\end{tabular} & 67813.5 & 6222.1 & 3023.5 & 7.8 & 2.66 \\
\hline Hualien & 25 & 20 & 60 & 17682.9 & 6122.5 & 760.7 & 167.5 & \begin{tabular}{|l|}
143527.1 \\
\end{tabular} & 74744.8 & 6184.0 & 2968.1 & 7.8 & 1.99 \\
\hline Taitung & 17 & 20 & 60 & 19368.4 & 11110.3 & 703.2 & 170.8 & \begin{tabular}{|l|l|}
145901.5 \\
\end{tabular} & 85452.8 & 5412.3 & 2336.4 & 7.4 & 1.91 \\
\hline Tainan & 24 & 20 & 39 & 10604.4 & 3305.6 & 458.0 & 118.6 & 88351.5 & 48149.4 & 3804.4 & 1873.1 & 8.0 & 1.55 \\
\hline Kaohsiung & 32 & 20 & 58 & 16089.5 & 6228.7 & 675.1 & 227.2 & \begin{tabular}{|l|}
169071.1 \\
\end{tabular} & 92288.1 & 7127.7 & 3515.3 & 10.5 & 2.68 \\
\hline Pingtung & 28 & 20 & 59 & 16500.1 & 6801.8 & 697.1 & 189.6 & \begin{tabular}{|l|}
175038.0 \\
\end{tabular} & 97840.0 & 7441.0 & 3642.6 & 10.3 & 2.48 \\
\hline Miaoli & 13 & 20 & 27 & 11554.1 & 4309.7 & 474.3 & 153.2 & 99973.8 & 56532.2 & 4088.8 & 2162.1 & 8.2 & 2.37 \\
\hline Taichung & 13 & 20 & 57 & 11290.5 & 4613.7 & 426.4 & 195.1 & \begin{tabular}{|l|}
101241.0 \\
\end{tabular} & 73276.8 & 4052.5 & 3824.4 & 8.6 & 3.14 \\
\hline Changhua & 6 & 20 & 24 & 5517.5 & 582.9 & 254.2 & 14.5 & 31201.6 & 5918.3 & 1433.6 & 205.3 & 5.6 & 0.55 \\
\hline Nantou & 35 & 20 & 60 & 12990.1 & 6947.6 & 499.5 & 137.8 & 98448.1 & 52217.4 & 3901.6 & 1981.5 & 7.7 & 2.76 \\
\hline Yunlin & 12 & 20 & 24 & 7070.5 & 3143.2 & 323.4 & 130.3 & 49891.5 & 37044.1 & 2261.2 & 1565.6 & 6.6 & 1.55 \\
\hline Chiyayi & 16 & 21 & 60 & \begin{tabular}{|l|}
15732.1 \\
\end{tabular} & 13295.2 & 543.6 & 262.5 & \begin{tabular}{|l|}
162113.1 \\
\end{tabular} & \begin{tabular}{|l}
174868.6 \\
\end{tabular} & 5481.0 & 4492.6 & 8.8 & 2.99 \\
\hline
\end{tabular}

Table 3. County wise mean and standard deviation values of accumulated precipitation, annual mean precipitation, $\mathrm{EI}_{30}$, R-factor and $\mathrm{R}$-factor density. Where Min. Max, SD represents the minimum, maximum, and standard deviation, respectively.

mean precipitation, rainfall erosivity for each county are computed and given in Table 3. Counties' mean accumulated precipitation varied from 5517.5-19368.39 $\mathrm{mm} \mathrm{yr}^{-1}$ with minimum precipitation over Changhua and maximum over Taitung. Annual mean R-factor ranges from 1433.59-7441.02 MJ mm ha ${ }^{-1} \mathrm{~h}^{-1} \mathrm{yr}^{-1}$ with minimum value over Changhua and maximum value over Pingtung. Lee and $\operatorname{Lin}^{46}$ estimated rainfall erosivity of 16560 storm events for Kaohsiung City and Pingtung County in south Taiwan. They found mean annual total rainfall between 1376-4070 $\mathrm{mm} \mathrm{yr}^{-1}$ and annual rainfall erosivity between $15000-70000 \mathrm{MJ} \mathrm{mm} \mathrm{ha-1} \mathrm{h}^{-1} \mathrm{yr}^{-1}$. The discrepancy in annual mean rainfall and rainfall erosivity values between present study and Lee and $\operatorname{Lin}^{46}$ is might be due to their adaptation of elsewhere KE-I relations or due to different sampling (10-min) of the rainfall data.

In order to identify the regions with high risk due to erosive events, typhoons rainfall erosivity density (ratio of annual R-factor to the annual mean precipitation) is computed for each station. For all the 288 rain gauges stations, erosivity density varies from $3.11-19.17 \mathrm{MJ} \mathrm{ha}^{-1} \mathrm{~h}^{-1}$ with mean and standard deviation of $7.92 \mathrm{MJ} \mathrm{ha}^{-1} \mathrm{~h}^{-1}$, and $2.79 \mathrm{MJ} \mathrm{ha}^{-1} \mathrm{~h}^{-1}$, respectively. The Island-wide gridded R-factor density values are derived by applying kriging interpolation to stations' R-factor density values. The R-factor density map of Taiwan (Fig. 3c) ranges from 4.57-9.68 $\mathrm{MJ} \mathrm{ha}^{-1} \mathrm{~h}^{-1}$ with mean and standard deviation of $7.77 \mathrm{MJ} \mathrm{ha}^{-1} \mathrm{~h}^{-1}$ and $0.99 \mathrm{MJ} \mathrm{ha}^{-1} \mathrm{~h}^{-1}$, respectively. Areas with higher erosivity density are an indication of locations with higher rainfall intensity events with shorter duration $^{29}$. Higher erosivity density values are noticed over southern part of Taiwan, which imply that southern part is most prone to the soil loss and high flood risk than other regions of Taiwan. The R-factor density values of each county of Taiwan are illustrated in Table 3. County wise R-factor density show minimum for Hsinchu (5.25 $\mathrm{MJ} \mathrm{ha} \mathrm{h}^{-1} \mathrm{~h}^{-1}$ and maximum for Kaohsiung (10.52 $\left.\mathrm{MJ} \mathrm{ha}^{-1} \mathrm{~h}^{-1}\right)$.

Trends in typhoons precipitation and erosivity. Quite diverse results were reported for rainfall erosivity trends over different parts of the world on seasonal and annual scale ${ }^{32,33,47-52}$. For instance, Webster et al. ${ }^{53}$, Emanuel ${ }^{1}$, and $\mathrm{Mei}$ and $\mathrm{Xie}^{54}$ noticed an increasing trend in the intensity of tropical cyclones, and in contrast, other researchers ${ }^{55,56}$ claim small or no trends. For Taiwan region, Tu et al..$^{57}$ demonstrated that an abrupt shift in typhoon count series from 3.3 (1970-1999) typhoons per year to 5.7 (2000-2006). Tu and Chou ${ }^{58}$ analyzed the frequency, intensity, and duration of typhoon-induced rainfall over Taiwan by considering 21 rain gauge stations distributed over this Island for July to October months during 1970-2010. They perceived a significant increase in typhoon-induced rainfall over Taiwan which is due to the increase in number of typhoon days that affecting the Island rather than number of typhoons that pass through the typhoons invading region $(18 \mathrm{~N}-29.5 \mathrm{~N}$, $116 \mathrm{E}-126 \mathrm{E}$ ). Recently, trend analysis for typhoon-induced rainfall at six rain gauges stations (along west coast: Taipei, Taichung, and Tainan; along east coast: Hualien, Taitung, and Hengchun) located over Taiwan was carried out by Liang et al. ${ }^{59}$. They showed that variations in the typhoon-induced rainfall trends at the selected six stations are related to the poleward shift of tropical cyclones over northwest Pacific, which is due to the weakening of the steering flow and western north Pacific subtropical high. Albeit, long-term trends in global tropical cyclones properties (number, intensity, duration, and destructive potential) have been documented ${ }^{1,53,54,60,61}$, trends in erosivity triggered by tropical cyclones rests unidentified.

Because of complex orography of Taiwan ${ }^{43}$, we performed trend analysis for Taiwan by considering different regions/counties rather than complete Island. Regions of this Island are classified into north (which include Taipei, Hsinchu, Taoyuan counties), central (Miaoli, Taichung, Changhua, Nantou, Yunlin, Chiayi), south (Tainan, Kaohsiung, Pingtung), and east (Yilan, Hualien, Taitung), and these regions are depicted with different color in Supplementary Fig. 1b. Trends in typhoons-induced annual mean precipitation and the corresponding 

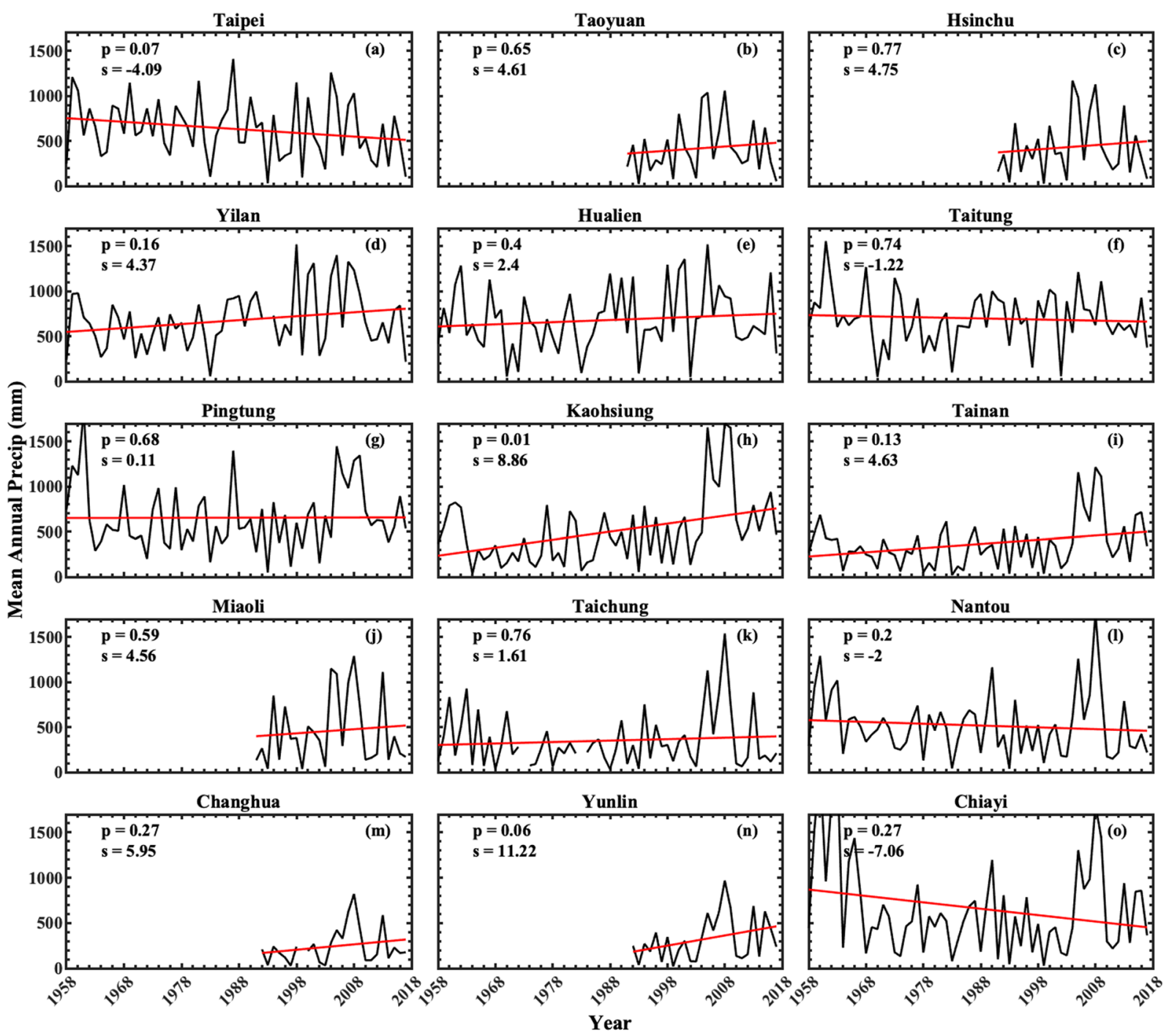

Figure 4. Time series of mean annual precipitation induced by typhoon rainfall events for 15 counties of Taiwan during 1958-2017. The rain gauge stations at Taoyuan, Hsinchu, and Maiaoli counties are available from the year 1991, and for Changhua and Yunlin from 1992. The slope of the trend line is depicted with 's' in the legend. The gaps in mean annual precipitations lines denotes unavailability of data for the corresponding year.

erosivity for 15 counties of Taiwan are illustrated in Figs 4 and 5, respectively. The linear trends for all 15 counties are performed by least square regression analysis. A trend is considered as significant if ' $\mathrm{p}$ ' value is less than 0.1 ( $90 \%$ confidence level).

Over north Taiwan, for the annual mean precipitations of typhoons-induced rainfall, except for Taipei county, which shows statistically significant decreasing trend (Fig. 4a), the other two counties (Taoyuan and Hsinchu; Fig. 4b,c) show slightly raising trends. For eastern Taiwan, Yilan and Hualien counties show raising trend (Fig. 4d,e) and the other county (Taitung) shows decreasing trend (Fig. 4f). On the other hand, all the three counties of south Taiwan show raising trends (Fig. 4g-i), with statistically significant raising trend only at Kaohsiung. Over Central Taiwan, except for Chiayi and Miaoli, which show decreasing trend (Fig. 4j,o), the other four counties (Miaoli, Taichung, Nantou, Changhua, and Yunlin (Fig. 4k-n) show raising trends, with statistically significant only at Yunlin.

Figure 5 depicts the time series of typhoons-induced rainfall erosivity for 15 counties of Taiwan. For north Taiwan, Taipei and Taoyuan show decreasing trends (Fig. 5a,b) and Hsinchu shows raising trend (Fig. 5c). However, the trends at these three counties are statistically insignificant. Increasing trends can be noticed for the three counties of eastern Taiwan (Fig. 5d-f), nevertheless, the trend is statistically significant only at Yilan county. Raising trends are also found for the three counties of south Taiwan (Fig. 5g-i) with statistically insignificant at Pingtung and significant at Kaohsiung and Tainan. Among six counties of central Taiwan, statistically significant raising trend at Yunlin (Fig. 5n), statistically insignificant decreasing trends at Miaoli (Fig. 5j) and Chiayi (Fig. 5o), and increasing trends at Taichung (Fig. 5k), Nantou (Fig. 5l) and Changhua (Fig. 5m) can be seen. 

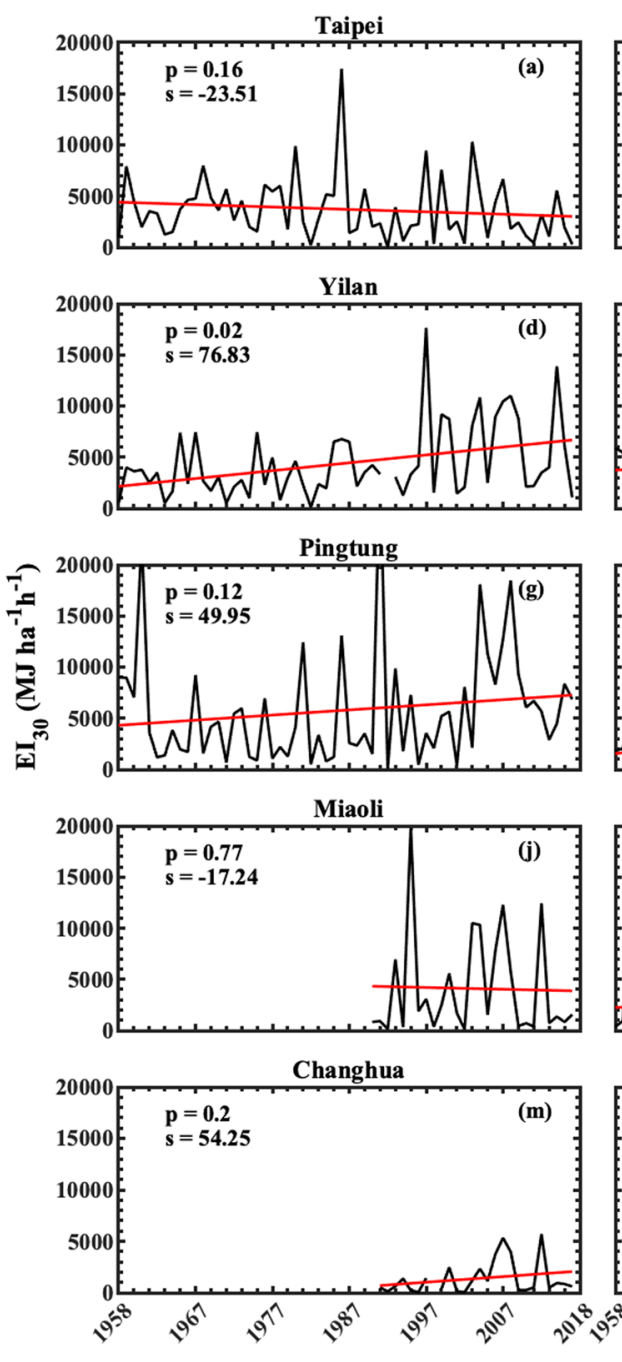

Figure 5. Same as Fig. 4 except for rainfall erosivity $\left(\mathrm{EI}_{30}\right)$.

\section{Discussion}

In computation of rainfall erosivity, most of the previous studies used either long-term rainfall data of few rain gauge stations $s^{47,52,62}$ or short-term data with dense rain gauges ${ }^{26,27,29}$ by using elsewhere KE-I relations rather than adopting region specific relations. Conversely, some researchers used modified Fournier index ${ }^{30}$ in estimation of erosivity, if there were no records of high temporal resolution precipitation data, and only few studies adopted the region specific KE-I relation in the reckoning of erosivity ${ }^{33}$. Nonetheless, globally, least attention was paid for the tropical cyclones-induced rainfall erosivity. Taiwan being most tropical cyclones affecting country, it is paramount to investigate the R-factor for typhoons rainfall.

In this study we used long-term raindrop size distribution information of typhoons to estimate the KE-I relations, and we establish that power law is more appropriate in estimating the Taiwan typhoons R-factor. The estimated KE-I relation is adopted in computing the typhoons R-factor with 60 years (1958-2017) of hourly rainfall data over Taiwan. The annual mean typhoons precipitation for Taiwan is noticed as 586.90 (SD 155.44) mm $\mathrm{yr}^{-1}$ with annual mean typhoons rainfall erosivity of 4905.83 (SD 1882.69) $\mathrm{MJ} \mathrm{mm} \mathrm{ha} \mathrm{mm}^{-1} \mathrm{~h}^{-1} \mathrm{yr}^{-1}$, which is much higher than the global mean ${ }^{31}$. Higher R-factor values are found over eastern and southern part of Taiwan, and higher R-factor density values are perceived for southern Taiwan. The typhoons invading region of Taiwan is surrounded by two major typhoons tracks in east and south direction (see Fig. 1 of Tu et al. ${ }^{44}$ ), and the interaction of typhoons that pass through these two major tracks interact with the CMR of the island resulting in an enormous rainfall amounts over eastern and southern region of Taiwan.

The county wise trend analysis performed for Taiwan showed increasing trends in rainfall and erosivity of typhoon events for eastern and southern Taiwan. Over northwest Pacific, during 1977-2013, Mei and Xie ${ }^{54}$ per- $^{-}$ formed the trend analysis for frequency of four types of typhoon clusters (cluster 1-4). Among the four clusters, they demonstrated an increase in high intense (category 4 and 5) typhoons of cluster- 1 and cluster-2, which are covered respectively, by eastern and southern Taiwan (Supplementary Fig. 8 of Mei and Xie ${ }^{54}$ ). An increasing 
trends in rainfall and erosivity over the eastern and southern region of this island is due to an increase in high intense, long-lasting typhoons and their shift to northward ${ }^{44,54,58}$.

In analyzing the trends for Taiwan, we consider all the typhoons that occurred throughout the year (Jan-Dec) during 1958-2017, and these typhoons should met an erosive event criteria as mentioned in methods sections. Also, we selected the rain gauge stations that are available for greater than or equal to 20 years of observation ( $\geq 20$ years) during typhoon-induced rainfall periods of 1958-2017. It should be noted that the typhoons whose rainfall amounts are not meeting the erosive event criteria are missing in the trend analysis. Moreover, because of complex topography of Taiwan, a given typhoon need not to produce the rainfall for the complete Island. Further, for a given typhoon-induced rainfall, all the rain gauges distributed over Taiwan may not get a rainfall event that satisfy the erosive event criteria, hence, some rain gauge stations record a rainfall event and some may not. Although there were reports on trends for typhoon-induced rainfall at different regions of Taiwan ${ }^{59}$, because of the above mentioned reasons, rainfall erosive events are not the representative of total rainfall of typhoons and their characteristics need not to be similar to that of the total rainfall amounts. Our findings can contribute to better assessment of soil erosion modeling, agricultural, effective-land use and flood risk assessment for Taiwan.

\section{Methods}

Study area. Taiwan is a subtropical island in the Western North Pacific $\left(\sim 36197 \mathrm{~km}^{2}\right)$ with geological composition of sedimentary and metamorphic rocks, and deep topographic CMR of average height $2 \mathrm{~km}$. Taiwan is influenced by highest annual frequency of tropical cyclones which are contributing to $47.5 \%$ of the total annual rainfall ${ }^{63}$. The geographical location of Taiwan with its topography, 711 rain gauge stations, and the JossWaldvogel disdrometer (JWD) ${ }^{64}$ is shown in Supplementary Fig. 1.

Typhoons tracks data. The typhoon track data is based on the World Meteorological Organization's Joint Typhoon Warning Center (JTWC) (http://www.usno.navy.mil/NOOC/nmfc-ph/RSS/jtwc/best_tracks/). The JTWC provides 6-hourly records of typhoon track information.

Disdrometer data selection criteria for typhoons rainfall. During 2002-2017, the raindrop size distribution measurements of disdrometer (1-min sample data) are treated as typhoon-induced rainfall when typhoon center (supplementary Fig. 2) is within a radius of $500 \mathrm{~km}$ from the disdrometer site ${ }^{65}$ and they are within the CWB typhoon warning periods.

Definition of erosive rainfall event. A rainfall episode with minimum duration of 30-min and rainfall depth of greater than or nearly equal to $12.5 \mathrm{~mm}$ and a 6-hours of continuous non-rainfall gap between two consecutive rainfall episodes is considered as erosive rainfall event ${ }^{13}$. Here we use erosive rainfall event criteria with rainfall depth of greater than or nearly equal to $10 \mathrm{~mm}$. With this rainfall classification criteria, a total number of 75 rainfall events from 66 typhoons are identified from the disdrometer measurements for the period 2002-2017.

Validation of Disdrometer data. The disdrometer rainfall amounts of selected typhoon rainfall events are validated by comparing with collocated rain gauge. The scatter plot of event rainfall depths between disdrometer and collocated rain gauge is depicted in Supplementary Fig. 3. A good correlation is found between the rain gauge and disdrometer measurements.

Computation of rainfall intensity $(\mathrm{I})$ and kinetic energy $\left(\mathrm{KE}_{\mathrm{mm}}\right.$ and $\left.\mathrm{KE}_{\mathrm{time}}\right)$. The rainfall intensity $\left(\mathrm{I}, \mathrm{mm} \mathrm{h}^{-1}\right)$, kinetic energy expenditure $\left(\mathrm{KE}_{\text {time }}, \mathrm{J} \mathrm{m}^{-2} \mathrm{~h}^{-1}\right)$, and kinetic energy content $\left(\mathrm{KE}_{\mathrm{mm}}, \mathrm{J} \mathrm{m}^{-2} \mathrm{~mm}^{-1}\right)$ for 75 typhoon rainfall events are computed from the RSD information of JWD.

The rainfall kinetic energy (KE) is half the product of raindrop mass and the square of its velocity, and can be expressed in two forms as time specific kinetic energy $\left(\mathrm{KE}_{\text {time, }}\right.$, in $\left.\mathrm{J} \mathrm{m}^{-2} \mathrm{~h}^{-1}\right)$ and volume specific kinetic energy $\left(\mathrm{KE}_{\mathrm{mm}}, \mathrm{J} \mathrm{m}^{-2} \mathrm{~mm}^{-1}\right) . \mathrm{KE}_{\text {time }}$ is kinetic energy per unit area per hour and $\mathrm{KE}_{\mathrm{mm}}$ is the kinetic energy per unit area per unit depth ${ }^{18-21}$.

The rainfall intensity and kinetic energy are computed by using below equations.

Rainfall intensity $\left(\mathrm{I}, \mathrm{mm} \mathrm{h}^{-1}\right)$,

$$
I=\left(\frac{\pi}{6}\right)\left(\frac{3.6}{10^{3}}\right)\left(\frac{1}{\mathrm{~A} \mathrm{~T}}\right) \sum_{\mathrm{i}=1}^{20} \mathrm{n}_{\mathrm{i}} \mathrm{D}_{\mathrm{i}}^{3}
$$

Kinetic energy expenditure $\left(\mathrm{KE}_{\text {time }}, \mathrm{J} \mathrm{m}^{-2} \mathrm{~h}^{-1}\right)$,

$$
\mathrm{KE}_{\text {time }}=\left(\frac{\pi}{12}\right)\left(\frac{1}{10^{6}}\right)\left(\frac{3600}{\mathrm{~T}}\right)\left(\frac{1}{\mathrm{~A}}\right) \sum_{\mathrm{i}=1}^{20} \mathrm{n}_{\mathrm{i}} \mathrm{D}_{\mathrm{i}} \mathrm{V}\left(\mathrm{D}_{\mathrm{i}}\right)^{2}
$$

Kinetic energy content $\left(\mathrm{KE}_{\mathrm{mm}}, \mathrm{J} \mathrm{m}^{-2} \mathrm{~mm}^{-1}\right)$,

$$
\mathrm{KE}_{\mathrm{mm}}=\frac{\mathrm{KE}_{\text {time }}}{\mathrm{I}}
$$

where $A=0.005 \mathrm{~m}^{2}$ is the sampling area of the sensor, $T=60 \mathrm{~s}$ is the sampling time, $n_{i}$ the number of drops of diameter $D_{i}, V\left(D_{i}\right)$ is the fall velocity of drops with diameter $\left(D_{i}\right)^{66}$.

In this study, data points with rainfall intensities less than $0.1 \mathrm{~mm} \mathrm{~h}^{-1}$ are discarded ${ }^{67}$. The $\mathrm{KE}_{\text {time }} \mathrm{I}$ and $\mathrm{KE}_{\mathrm{mm}}{ }^{-\mathrm{I}}$ empirical relations are derived for linear, exponential, logarithmic, and power laws by using non-linear regression analysis. 
Rain gauge data selection criteria for typhoons rainfall. For the period of 1958-2017, hourly rain gauges data during central weather Bureau (CWB) typhoon warning periods (http://rdc28.cwb.gov.tw/TDB/ ntdb/pageControl/typhoon) of Taiwan are considered as typhoons attributed rainfall.

Rain gauge stations selection criteria. In this study, we selected the rain gauge stations with minimum record of 20 years for the estimation of R-factor, with this threshold, among the dense network of 711 rain gauge stations distributed over Taiwan, a total number of 288 stations are qualified for typhoons rainfall record periods of 20 years or higher during 1958-2017. At these 288 rain gauge station, during 1958-2017, a typhoon-induced rainfall amount is considered for further analysis (estimation of R-factor and R-factor density) if it satisfy the erosive rainfall event criteria as mentioned above.

Calculation of $\mathrm{R}$-factor $\left(\mathrm{El}_{30}\right)$. The average annual typhoon rainfall erosivity $(\mathrm{R})$ is computed as:

$$
R=\frac{1}{\mathrm{n}} \sum_{\mathrm{j}=1}^{\mathrm{n}} \sum_{\mathrm{k}=1}^{\mathrm{m}_{\mathrm{j}}}\left(\mathrm{EI}_{30}\right)_{\mathrm{k}}
$$

where R-factor is the average annual rainfall erosivity $\left(\mathrm{MJ} \mathrm{mm} \mathrm{ha} \mathrm{m}^{-1} \mathrm{~h}^{-1} \mathrm{yr}^{-1}\right), \mathrm{n}$ is the number of years of record, $\mathrm{m}_{\mathrm{j}}$ is the number of erosive events of a given year $\mathrm{j}$, and $\mathrm{EI}_{30}$ is the typhoon rainfall erosivity index of a single event $\mathrm{k}$.

The single event erosivity $\mathrm{EI}_{30}\left(\mathrm{MJ} \mathrm{mm} \mathrm{ha}{ }^{-1} \mathrm{~h}^{-1}\right)$ is defined as:

$$
\mathrm{EI}=\mathrm{EI}_{30}=\mathrm{eI}_{30}
$$

where $\mathrm{I}_{30}$ is the maximum 30-min rainfall intensity $\left(\mathrm{I}, \mathrm{mm} \mathrm{h}^{-1}\right)$ and is calculated by adopting the method of Yin et al. ${ }^{68}$. Where $e$ is the rainfall kinetic energy per unit depth of rain and is obtained by using power law of $\mathrm{KE}_{\text {time }}-\mathrm{I}$ relation:

$$
\mathrm{KE}_{\text {time }}=\mathrm{aI}^{\mathrm{b}}
$$

where 'a' and 'b' are empirical coefficients

$$
\mathrm{e}=\frac{\mathrm{KE}_{\text {time }}}{\mathrm{I}}=\frac{\mathrm{aI}^{\mathrm{b}}}{\mathrm{I}}=\mathrm{aI}^{\mathrm{b}-1}
$$

Annual R-factor values are used to drive rainfall erosivity maps by using ordinary kriging.

The annual mean precipitation value at each rain gauge station is computed by using the expression as mentioned below.

$$
\text { Annual mean precipitation at each rain gauge station }=\frac{\sum_{j=1}^{m} \sum_{i=1}^{n} P_{i, j}}{m}
$$

where ' $n$ ' represents the number of events in a given year for a given station, and ' $m$ ' represents the number of years that have typhoon-induced rainfall events for a given station, and " $\mathrm{P}_{\mathrm{i}, \mathrm{j}}$ " is typhoon-induced rainfall accumulation of $\mathrm{n}^{\text {th }}$ event in $\mathrm{m}^{\text {th }}$ year.

The annual mean $\mathrm{EI}_{30}$ value at each rain gauge station is computed by using the expression as mentioned below.

$$
\text { Annual mean } \mathrm{EI}_{30} \text { at each rain gauge station }=\frac{\sum_{j=1}^{m} \sum_{i=1}^{n} X_{i, j}}{m}
$$

where ' $n$ ' represents the number of events in a given year for a given station, and ' $m$ ' represents the number of years that have typhoon-induced rainfall events for a given station, and " $\mathrm{X}_{\mathrm{i}, \mathrm{j}}$ " is $\mathrm{EI}_{30}$ of a typhoon-induced rainfall of $\mathrm{n}^{\text {th }}$ event in $\mathrm{m}^{\text {th }}$ year.

Kriging interpolation is applied to annual mean precipitation and annual $\mathrm{EI}_{30}$ values available at Island wide distributed 288 rain gauge stations (whose record period $\geq 20$ years during 1958-2017) to plot the spatial distribution (Island-wide gridded data) map for annual mean precipitation and annual $\mathrm{EI}_{30}$.

Received: 29 March 2019; Accepted: 8 October 2019;

Published online: 01 November 2019

\section{References}

1. Emanuel, K. Increasing Destructiveness of Tropical Cyclones Over the Past 30 Years. Nature 436, 686-688, https://doi.org/10.1038/ nature03906 (2005).

2. Peduzzi, P. et al. Global Trends in Tropical Cyclone Risk. Nat. Clim. Change 2, 289 (2012).

3. Lin, I. I. \& Chan, J. C. Recent Decrease in Typhoon Destructive Potential and Global Warming Implications. Nat. Commun. 6, 7182, https://doi.org/10.1038/ncomms8182 (2015).

4. Wu, C.-C. \& Kuo, Y.-H. Typhoons Affecting Taiwan: Current Understanding and Future Challenges. Bull. Amer. Meteor. Soc. 80, 67-80, 10.1175/1520-0477(1999)080<0067:TATCUA > 2.0.CO;2 (1999).

5. Galewsky, J. et al. Tropical Cyclone Triggering of Sediment Discharge in Taiwan. J. Geophys. Res.: Earth Surface 111, n/a-n/a, https:// doi.org/10.1029/2005jf000428 (2006).

6. Montgomery, D. R., Huang, M. Y. F. \& Huang, A. Y. L. Regional Soil Erosion in Response to Land use and Increased Typhoon Frequency and Intensity, Taiwan. Quat. Res. 81, 15-20, https://doi.org/10.1016/j.yqres.2013.10.005 (2014). 
7. Dadson, S. J. et al. Links between erosion, runoff variability and seismicity in the Taiwan orogen. Nature 426, 648, https://doi. org/10.1038/nature02150, https://www.nature.com/articles/nature02150\#supplementary-information (2003).

8. Chen, Y.-C., Chang, K.-T., Chiu, Y.-J., Lau, S.-M. \& Lee, H.-Y. Quantifying Rainfall Controls on Catchment-Scale landslide Erosion in Taiwan. Earth Surf. Process Landf. 38, 372-382, https://doi.org/10.1002/esp.3284 (2013).

9. Chen, Y.-C., Chang, K.-T., Lee, H.-Y. \& Chiang, S.-H. Average Landslide Erosion Rate at the Watershed Scale in Southern Taiwan Estimated from Magnitude and Frequency of Rainfall. Geomorphology 228, 756-764, https://doi.org/10.1016/j. geomorph.2014.07.022 (2015).

10. Chen, C.-W. et al. Assessing Landslide Characteristics in a Changing Climate in Northern Taiwan. Catena 175, 263-277, https://doi. org/10.1016/j.catena.2018.12.023 (2019).

11. Lin, G.-W. \& Chen, H. The Relationship of Rainfall Energy with Landslides and Sediment Delivery. Eng. Geol. 125, 108-118, https:// doi.org/10.1016/j.enggeo.2011.11.010 (2012).

12. Wischmeier, W. H. A Rainfall Erosion Index for a Universal Soil-Loss Equation 1. Soil Sci. Soc. Am. J. 23, 246-249, https://doi. org/10.2136/sssaj1959.03615995002300030027x (1959).

13. Wischmeier, W. H. \& Smith, D. D. Predicting Rainfall Erosion Losses - A Guide to Conservation Planning. (USDA, Science and Education Administration, 1978).

14. Renard, K. G., Foster, G. R., Weesies, G. A., McCool, D. K. \& Yoder, D. C. Predicting Soil Erosion by Water: A Guide to Conservation Planning with the Revised Universal Soil Loss Equation (RUSLE) (Agricultural Handbook 703). (US Department of Agriculture, 1997).

15. Borrelli, P. et al. An Assessment of the Global Impact of 21st Century Land Use Change on Soil Erosion. Nat. Commun. 8, 2013, https://doi.org/10.1038/s41467-017-02142-7 (2017).

16. Madden, L. V., Wilson, L. L. \& Ntahimpera, N. Calibration and Evaluation of an Electronic Sensor for Rainfall Kinetic Energy. Phytopathology 88, 950-959, https://doi.org/10.1094/PHYTO.1998.88.9.950 (1998).

17. Jayawardena, A. W. \& Rezaur, R. B. Measuring Drop Size Distribution and Kinetic Energy of Rainfall Using a Force Transducer. Hydrol. Process. 14, 37-49, 10.1002/(SICI)1099-1085(200001)14:1<37::AID-HYP908>3.0.CO;2-M (2000).

18. Kinnell, P. I. A. Rainfall Intensity-Kinetic Energy Relationships for Soil Loss Prediction1. Soil Sci. Soc. Am. J. 45, 153-155, https:// doi.org/10.2136/sssaj1981.03615995004500010033x (1981).

19. Fornis, R. L., Vermeulen, H. R. \& Nieuwenhuis, J. D. Kinetic Energy-Rainfall Intensity Relationship For Central Cebu, Philippines for Soil Erosion Studies. J. Hydrol. 300, 20-32, https://doi.org/10.1016/j.jhydrol.2004.04.027 (2005).

20. van Dijk, A. I. J. M., Bruijnzeel, L. A. \& Rosewell, C. J. Rainfall Intensity-Kinetic Energy Relationships: A Critical Literature Appraisal. J. Hydrol. 261, 1-23, https://doi.org/10.1016/S0022-1694(02)00020-3 (2002).

21. Salles, C., Poesen, J. \& Sempere-Torres, D. Kinetic Energy of Rain and Its Functional Relationship With Intensity. J. Hydrol. 257, 256-270, https://doi.org/10.1016/S0022-1694(01)00555-8 (2002).

22. Sempere-Torres, D., Salles, C., Creutin, J. D. \& Delrieu, G. In Erosion and Sediment Transport Monitoring Programmes in River Basins (Proceedings of the Oslo Symposium, August 1992) Vol. 210 115-124 (IAHS Publ., 1992).

23. Rosewell, C. J. Rainfall Kinetic Energy in Eastern Australia. J. Appl. Meteorol. Climatol. 25, 1695-1701, 10.1175/1520-0450(1986)025<1695:RKEIEA > 2.0.CO;2 (1986).

24. Uijlenhoet, R. \& Stricker, J. N. M. A Consistent Rainfall Parameterization Based on the Exponential Raindrop Size Distribution. J. Hydrol. 218, 101-127, https://doi.org/10.1016/S0022-1694(99)00032-3 (1999).

25. Wischmeier, W. H. \& Smith, D. D. Rainfall Energy and its Relationship to Soil Loss. T. Am. Geophys. Un. 39, 285-291, https://doi. org/10.1029/TR039i002p00285 (1958)

26. Sadeghi, S. H., Zabihi, M., Vafakhah, M. \& Hazbavi, Z. Spatiotemporal Mapping of Rainfall Erosivity Index for Different Return Periods in Iran. Nat. Hazards 87, 35-56, https://doi.org/10.1007/s11069-017-2752-3 (2017).

27. Borrelli, P., Diodato, N. \& Panagos, P. Rainfall Erosivity in Italy: a National Scale Spatio-temporal. Assessment. Int. J. Digit. Earth 9 , 835-850, https://doi.org/10.1080/17538947.2016.1148203 (2016).

28. Mondal, A., Khare, D. \& Kundu, S. Change in Rainfall Erosivity in the Past and Future due to Climate Change in the Central Part of India. Int. Soil Water Conserv. Res. 4, 186-194, https://doi.org/10.1016/j.iswcr.2016.08.004 (2016).

29. Panagos, P. et al. Rainfall Erosivity in Europe. Science of Total Environment 511, 801-814, https://doi.org/10.1016/j. scitotenv.2015.01.008 (2015).

30. Fenta, A. A. et al. Spatial Distribution and Temporal Trends of Rainfall and Erosivity in the Eastern Africa Region. Hydrol. Process. 31, 4555-4567, https://doi.org/10.1002/hyp.11378 (2017).

31. Panagos, P. et al. Global Rainfall Erosivity Assessment Based on High-temporal Resolution Rainfall Records. Sci. Rep. 7, 4175, https://doi.org/10.1038/s41598-017-04282-8 (2017).

32. Laceby, J. P. et al. Rainfall Erosivity in Catchments Contaminated with Fallout from the Fukushima Daiichi Nuclear Power Plant Accident. Hydrol. Earth Syst. Sci. 20, 2467-2482, https://doi.org/10.5194/hess-20-2467-2016 (2016).

33. Verstraeten, G., Poesen, J., Demarée, G. \& Salles, C. Long-term (105 years) Variability in Rain Erosivity as Derived from 10-min Rainfall Depth Data for Ukkel (Brussels, Belgium): Implications for Assessing Soil Erosion Rates. J Geophys. Res. 111, https://doi. org/10.1029/2006jd007169 (2006).

34. Parsons, A. J. \& Gadian, A. M. Uncertainty in Modelling the Detachment of Soil by Rainfall. Earth Surf. Process Landf. 25, 723-728, 10.1002/1096-9837(200007)25:7<723::AID-ESP127>3.0.CO;2-X (2000).

35. Catari, G., Latron, J. \& Gallart, F. Assessing the Sources of Uncertainty Associated with the Calculation of Rainfall Kinetic Energy and Erosivity - Application to the Upper Llobregat Basin, NE Spain. Hydrol. Earth Syst. Sci. 15, 679-688, https://doi.org/10.5194/ hess-15-679-2011 (2011).

36. Lu, J. Y., Su, C. C., Lu, T. F. \& Maa, M. M. Number and Volume Raindrop Size Distributions in Taiwan. Hydrol. Process. 22, 2148-2158, https://doi.org/10.1002/hyp.6814 (2008).

37. Chang, J. M., Chen, H. E., Jou, B. J. D., Tsou, N. C. \& Lin, G. W. Characteristics of Rainfall Intensity, Duration, and Kinetic Energy for Landslide Triggering in Taiwan. Eng. Geol. 231, 81-87, https://doi.org/10.1016/j.enggeo.2017.10.006 (2017).

38. Kumar, S. B. \& Reddy, K. K. Rain Drop Size Distribution Characteristics of Cyclonic and North East Monsoon Thunderstorm Precipitating Clouds Observed over Kadapa $\left(14.47^{\circ} \mathrm{N}, 78.82^{\circ} \mathrm{E}\right)$, Tropical Semi-arid Region of India. Mausam 64, 35-48 (2013).

39. Deo, A. \& Walsh, K. J. E. Contrasting Tropical Cyclone and Non-tropical Cyclone Related Rainfall Drop Size Distribution at Darwin, Australia. Atmos. Res. 181, 81-94, https://doi.org/10.1016/j.atmosres.2016.06.015 (2016).

40. Nanko, K., Moskalski, S. M. \& Torres, R. Rainfall Erosivity-Intensity Relationships for Normal Rainfall Events and a Tropical Cyclone on the US Southeast Coast. J. Hydrol. 534, 440-450, https://doi.org/10.1016/j.jhydrol.2016.01.022 (2016).

41. Steiner, M. \& Smith, J. A. Reflectivity, Rain Rate, and Kinetic Energy Flux Relationships Based on Raindrop Spectra. J. Appl. Meteorol. 39, 1923-1940, 10.1175/1520-0450(2000)039<1923:RRRAKE > 2.0.CO;2 (2000).

42. Chang, C. P., Yeh, T. C. \& Chen, J. M. Effects of Terrain on the Surface Structure of Typhoons over Taiwan. Mon. Weather Rev. 121, 734-752, 10.1175/1520-0493(1993) $121<0734:$ EOTOTS >2.0.CO;2 (1993).

43. Cheung, K. K. W., Huang, L. R. \& Lee, C. S. Characteristics of Rainfall During Tropical Cyclone Periods in Taiwan. Nat. Hazards Earth Syst. Sci. 8, 1463-1474, https://doi.org/10.5194/nhess-8-1463-2008 (2008).

44. Tu, J.-Y., Chou, C. \& Chu, P.-S. The Abrupt Shift of Typhoon Activity in the Vicinity of Taiwan and Its Association with Western North Pacific-East Asian Climate Change. J. Climate 22, 3617-3628, https://doi.org/10.1175/2009JCLI2411.1 (2009). 
45. García-Oliva, F., Maass, J. M. \& Galicia, L. Rainstorm Analysis and Rainfall Erosivity of a Seasonal Tropical Region with a Strong Cyclonic Influence on the Pacific Coast of Mexico. J. Appl. Meteorol. 34, 2491-2498, 10.1175/1520-0450(1995)034<2491:RAAREO >2.0.CO;2 (1995).

46. Lee, M.-H. \& Lin, H.-H. Evaluation of Annual Rainfall Erosivity Index Based on Daily, Monthly, and Annual Precipitation Data of Rainfall Station Network in Southern Taiwan. Int. J. Distr. Sensor Net. 11, https://doi.org/10.1155/2015/214708 (2015).

47. Sadeghi, S. H. R. \& Hazbavi, Z. Trend analysis of the rainfall erosivity index at different time scales in Iran. Nat. Hazards 77, 383-404, https://doi.org/10.1007/s11069-015-1607-z (2015).

48. Huang, J., Zhang, J., Zhang, Z. \& Xu, C.-Y. Spatial and Temporal Variations in Rainfall Erosivity During 1960-2005 in the Yangtze River Basin. Stoch Environ Res Risk Assess. 27, 337-351, https://doi.org/10.1007/s00477-012-0607-8 (2013).

49. Fiener, P., Neuhaus, P. \& Botschek, J. Long-term Trends in Rainfall Erosivity-Analysis of High Resolution Precipitation Time Series (1937-2007) from Western Germany. Agric. For. Meteorol. 171-172, 115-123, https://doi.org/10.1016/j.agrformet.2012.11.011 (2013).

50. Xin, Z., Yu, X., Li, Q. \& Lu, X. X. Spatiotemporal Variation in Rainfall Erosivity on the Chinese Loess Plateau During the Period 1956-2008. Reg. Environ. Change 11, 149-159, https://doi.org/10.1007/s10113-010-0127-3 (2011).

51. Li, X. \& Ye, X. Variability of Rainfall Erosivity and Erosivity Density in the Ganjiang River Catchment, China: Characteristics and Influences of Climate Change. Atmosphere 9, https://doi.org/10.3390/atmos9020048 (2018).

52. Angulo-Martínez, M. \& Beguería, S. Trends in Rainfall Erosivity in NE Spain at Annual, Seasonal and Daily Scales. Hydrol. Earth Syst. Sci. 16, 3551-3559, https://doi.org/10.5194/hess-16-3551-2012 (2012).

53. Webster, P. J., Holland, G. J., Curry, J. A. \& Chang, H.-R. Changes in Tropical Cyclone Number, Duration, and Intensity in a Warming Environment. Science 309, 1844-1846 (2005).

54. Mei, W. \& Xie, S.-P. Intensification of landfalling typhoons over the northwest Pacific since the late 1970s. Nat. Geosci. 9, 753, https:// doi.org/10.1038/ngeo2792, https://www.nature.com/articles/ngeo2792\#supplementary-information (2016).

55. Landsea, C. W. Hurricanes and global warming. Nature 438, E11-E12, https://doi.org/10.1038/nature04477 (2005).

56. Chan, J. C. Comment on "Changes in tropical cyclone number, duration, and intensity in a warming environment". Science 311, 1713-1713 (2006).

57. Tu, J.-Y., Chou, C., Huang, P. \& Huang, R. An abrupt increase of intense typhoons over the western North Pacific in early summer. Environ. Res. Lett. 6, 034013, https://doi.org/10.1088/1748-9326/6/3/034013 (2011).

58. Tu, J.-Y. \& Chou, C. Changes in precipitation frequency and intensity in the vicinity of Taiwan: typhoon versus non-typhoon events. Environ. Res. Lett. 8, 014023, https://doi.org/10.1088/1748-9326/8/1/014023 (2013).

59. Liang, A., Oey, L., Huang, S. \& Chou, S. Long-term Trends of Typhoon-induced Rainfall Over Taiwan: In-situ Evidence of Poleward Shift of Typhoons in Western North Pacific in Recent Decades. J. Geophys. Res. Atmos. 122, 2750-2765, https://doi. org/10.1002/2017JD026446 (2017).

60. Chan, J. C. L. \& Shi, J.-E. Long-term Trends and Interannual Variability in Tropical Cyclone Activity over the Western North Pacific. Geophy. Res. Lett. 23, 2765-2767, https://doi.org/10.1029/96GL02637 (1996).

61. Knutson, T. R. et al. Tropical cyclones and climate change. Nat. Geosci. 3, 157, https://doi.org/10.1038/ngeo779, https://www.nature. com/articles/ngeo779\#supplementary-information (2010).

62. Zhao, Q. et al. Spatiotemporal Variations in Rainfall Erosivity During the Period of 1960-2011 in Guangdong Province, Southern China. Theoritical and Applied Climatology 128, 113-128, https://doi.org/10.1007/s00704-015-1694-5 (2017).

63. Chen, J.-M., Li, T. \& Shih, C.-F. Tropical Cyclone- and Monsoon-Induced Rainfall Variability in Taiwan. J. Climate 23, 4107-4120, https://doi.org/10.1175/2010jcli3355.1 (2010).

64. Joss, J. \& Waldvogel, A. Raindrop Size Distribution and Sampling Size Errors. J. Atmos. Sci. 26, 566-569, 10.1175/1520-0469(1969)026<0566:RSDASS >2.0.CO;2 (1969).

65. Jiang, H. \& Zipser, E. J. Contribution of Tropical Cyclones to the Global Precipitation from Eight Seasons of TRMM Data: Regional, Seasonal, and Interannual Variations. J. Climate 23, 1526-1543, https://doi.org/10.1175/2009jcli3303.1 (2010).

66. Gunn, R. \& Kinzer, G. D. The Terminal Velocity of Fall for Water Droplets in Stagnant Air. J. Meteor. 6, 243-248, 10.1175/1520-0469(1949)006<0243:TTVOFF $>2.0$. CO;2 (1949).

67. Tokay, A. \& Short, D. A. Evidence from Tropical Raindrop Spectra of the Origin of Rain from Stratiform versus Convective Clouds. J. Appl. Meteorol. 35, 355-371, 10.1175/1520-0450(1996)035<0355:EFTRSO > 2.0.CO;2 (1996).

68. Yin, S., Xie, Y., Nearing, M. A. \& Wang, C. Estimation of Rainfall Erosivity Using 5- to 60-minute Fixed-interval Rainfall Data from China. Catena 70, 306-312, https://doi.org/10.1016/j.catena.2006.10.011 (2007).

\section{Acknowledgements}

The authors would like to acknowledge the Central Weather Bureau, Taiwan for providing the rain gauge stations data. All the authors are also thank Joint typhoon warning center (JTWC) for providing the typhoon track information. This work is supported by Ministry of Science and Technology (MOST), Taiwan under grants no. MOST 104-2923-M-008-003-MY5, MOST 106-2625-M-008-013 and MOST 106-2811-M-008-084, partially by "Earthquake-Disaster \& Risk Evaluation and Management Center, E-DREaM" from The Featured Areas Research Center Program within the framework of the Higher Education Sprout Project by the Ministry of Education (MOE), Taiwan. The first author, JJ acknowledges MOST, Taiwan to carry out this research work under grants MOST 104-2811-M-008-064, MOST 106-2811-M-008-084, MOST 107-2811-M-008-2551 and MOST 108-2811M-008-558. BKS acknowledges the Academia Sinica, Taiwan for providing the graduate fellowship under Taiwan international Graduate Program (TIGP), and also to MOST, Taiwan, R.O.C for providing the fellowship under the grant numbers MOST 106-2625-M-008-013 and MOST 107-2625-M-008-002.

\section{Author contributions}

J.J., B.K.S. and P.L.L. provided the study concept. J.J. and B.K.S. performed data analysis and interpretation. P.L.L. archived the data, conceived the project, and provided the fund opportunities. J.J. and B.K.S. wrote the manuscript. J.J., B.K.S., P.L.L. and P.K.W. involved in drafting and revising the manuscript. UK involved in data analysis. All the authors reviewed and commented the manuscript.

\section{Competing interests}

The authors declare no competing interests.

\section{Additional information}

Supplementary information is available for this paper at https://doi.org/10.1038/s41598-019-52028-5.

Correspondence and requests for materials should be addressed to P.-L.L. 
Reprints and permissions information is available at www.nature.com/reprints.

Publisher's note Springer Nature remains neutral with regard to jurisdictional claims in published maps and institutional affiliations.

(c) (i) Open Access This article is licensed under a Creative Commons Attribution 4.0 International License, which permits use, sharing, adaptation, distribution and reproduction in any medium or format, as long as you give appropriate credit to the original author(s) and the source, provide a link to the Creative Commons license, and indicate if changes were made. The images or other third party material in this article are included in the article's Creative Commons license, unless indicated otherwise in a credit line to the material. If material is not included in the article's Creative Commons license and your intended use is not permitted by statutory regulation or exceeds the permitted use, you will need to obtain permission directly from the copyright holder. To view a copy of this license, visit http://creativecommons.org/licenses/by/4.0/.

(C) The Author(s) 2019 